\title{
Women Owners Of SMMEs: Finding Their Place In The Sun
}

Orpha Cilliers, University of South Africa, South Africa

Johan Strydom, University of South Africa, South Africa

\begin{abstract}
Women business ownership is cardinal for long-term economic growth. Research provides divergent reasonsfor the difference in the characteristics of SMMEs owned by women and those owned by men. In this study, a quantitative survey was conducted among 650 formal SMMEs in Soweto Township, South Africa, using questionnaires. A third of the respondents comprised women, who were characterised as generally being older $(67.6 \%$ were over the age of 40$)$, having a higher level of education (11.1\% had three years or more of tertiary education) and being involved on a fulltime basis in SMMEs (100\%). When compared with their male counterparts, fewer young women were involved in business ownership, and a sizeable component of older women-owners/managers exists. No major difference regarding education was found between genders. Both gender groups started their businesses mainly because of unemployment. Far more women respondents than men located their businesses in small shopping centres. The results also showed that more women were in business for more than five years and that more women-owned businesses showed growth in income over the preceding year. These findings are aligned with national and international surveys which show that the gap between men and women business owners is narrowing. Finally, the results showed a need for support programmes focused on empowering both genders to succeed in all phases of the business life cycle, with a primary need for improved marketing skills. Business support programmes can be successful only if improved communication is established between programme developers and business owners.
\end{abstract}

Keywor ds: Women-Owned Businesses; SMMEs; Soweto Township; Support Programmes; South Africa

\section{INTRODUCTION}

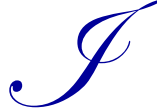

$\mathrm{t}$ is widely recognised that small businesses play an important role in stimulating economic growth and creating job opportunities. In particular, women's involvement in entrepreneurial activity and business ownership seems cardinal for long-term economic growth (Tagg \& Wilson, 2012). Worldwide, the economic empowerment of women has become a prominent way to reduce poverty and ultimately lessen the universal effect of inequality based on gender. The substantial growth in female business activity rates worldwide is in tandem with the research developments in the field of gender in small business ownership. The main reasons for prioritising women in business in developing countries are confirmed by Minniti and Naudé (2010:280) as the following: first, women have only to gain from being involved in business due to their perceived gender position of being poorer and discriminated against; and second, there has been a rapid increase in female entrepreneurship activity in developing countries in general. Minniti and Naudé (2010:280) also describe women entrepreneurs as a critical driver in promoting entrepreneurship in developing countries based on their unique role within households and the increased number of households headed by women. Such changes in household roles can result in a situation where women owning small businesses can significantly influence household spending on essentials (such as health, nutrition and education), which could ultimately reduce poverty and increase the quality of life in households and countries in general. Despite the fact that Scott, Dolan, Johnstone-Louis, Sugden and Wu (2012:564) described the goal of empowering businesswomen beyond the constraints of patriarchy and support as "naïve and fundamentally subversive", the general expected positive outcome of successfully empowering women business owners in society seems to be undisputed. Divergent opinions on the growth patterns and the reasons for the existence (or absence) of growth experienced by women-owned businesses are found in the literature. In this regard, Marlow (2014) blames the absence of a theoretical framing where the assumptions informing the normative model of performance are not representing women-owned businesses. Contributing to the success of women-owned businesses is advocated prominently worldwide and forms the driving force behind research and subsequent support programmes developed 
to promote business ownership by women specifically. Research reports on this topic include the 2014 Gender Global Entrepreneurship and Development Index (GEDI, 2014), the 2012 Global Entrepreneurship Monitor Women's Report (Global Entrepreneurship Monitor 2012 Women's Report) and The Global Gender Gap Report 2014 (World Economic Forum, 2014), which will be referred to in this article.

\section{RESEARCH PROBLEM}

Since women business owners are critical role players in addressing poverty in developing countries, the main aim of this study was to provide an overview of the state of women-owned businesses in the Soweto Township as part Johannesburg, which forms the economic hub of South Africa. The key profile aspects of retail SMMEs in the township (as the majority of the respondents) were investigated, followed by an analysis of the position of women business owners (in terms of business age, length of time in business and increased turnover) to determine whether they are an established force to be reckoned with in the township business environment. This article focuses on determining whether the gap between genders in terms of business ownership has narrowed in South African small business as is the case worldwide. Based on the findings, recommendations follow on the type of support needed in the empowerment of South African SMMEs.

\section{UNDERS TANDING THE TERMINOLOGY}

In this study the concepts of entrepreneur, small business owner, small business, South African retail sector and Soweto Township need to be clarified.

The concepts "entrepreneur" and "small business owner" (or owner/manager) are often used interchangeably in research without acknowledgement of any difference in meaning (Tagg \& Wilson, 2012). It would be extremely helpful if all literature and research findings were to acknowledge the difference between entrepreneurs and small business owners as Greenbank (2001:123) has done, and not perceive them as a homogeneous group or differentiate according to gender. The correct use of these concepts could contribute to a better understanding of women business owners' apparent lack of drive to initiate change despite experiencing declining business performance. Greenbank's (2001) research focused on the different types of objectives, as well as the different definitions of success that entrepreneurs and small business owners apply in operating their businesses. Greenbank (2001:108-110), as referred to by Simpson, Tuck and Bellamy (2004:484), holds that small business success is defined by business owners in terms of personal goals and by entrepreneurs in terms of business growth. This finding could explain why business owners (irrespective of gender) might tend to show satisficing behaviour (which implies being satisfied with satisfactory performance instead of maximum performance) due to individual, social and economic influences and also why business owners are subsequently not driven by business growth, sales and profitability. The same sentiment is conveyed by Nieuwenhuizen (2012:3-4) when she explains that a true entrepreneur (who is characterised by continuous creativity and innovation) can evolve into a business owner/manager (who has an aversion to risk, change and innovation) when the entrepreneur becomes comfortable and satisfied with the business. However, since the majority of the literature does not draw a consistent and clear distinction between the concepts of entrepreneurs and small business owners, the interpretation of literature findings for the purposes of this study will have to be based on viewing these concepts as synonyms. The empirical findings in this study will focus on women small business owner/managers, specifically those operating in the retail sector of South Africa and, more specifically, the Soweto Township area.

For the purpose of this study a small business will be as defined by the National Small Business Amendment Act of 2004 whereby a South African small business refers to "a separate and distinct business entity, together with its branches or subsidiaries, if any, including co-operative enterprises and non-governmental organisations, managed by one owner or more which, including its branches or subsidiaries, if any, is predominantly carried on in any sectoror subsector of the economy and which can be classified as a micro-, a very small, a small or medium enterprise." The acronym SMME will be used when discussing the research design and empirical findings of this study to reflect the profile of the respondent group. Since the concepts of SME, SMME and small business are used interchangeably in literature, these concepts will be used in the way that they are presented in literature. 
The South African retail sector can be defined by using the classifications from the Standard Industrial Clas sification (SIC) from Statistics South Africa, which includes the reselling (sale without transformation) of new and used goods to the general public for personal or household consumption or use by businesses, such as shops, department stores, stalls, mail-order houses, hawkers and peddlers and consumer cooperatives. This study focuses on analysing respondents in the retail sectorfor twee reasons. Firstly, authors agree that women-owned businesses generally tend to be concentrated in the retail and service industries, which have lower entrance requirements and which seem to better suit the work-life situation women business owners have to manage (Scarborough, 2011:34; Deakins \& Freel, 2012:84; SBP, 2013:1). Secondly, retailer businesses form the majority of the respondent group analysed in this article. The specific type of retail activity performed by the retail respondents is, however, not included in his article.

Soweto (acronym for South Western Township) is the largest formerly disadvantaged township in South Africa where non-white people had to live by law under the previous political and social dispensation (before 1994).

\section{LITERATURE BACKGROUND}

The subsequent discussion will focus on the general state of women business ownership worldwide as described by various authors performing research in both developing and developed countries, after which the discussion will focus on the South African situation and the position of women small business owners in Soweto Township in particular. The relevance of the physical location decision in small businesses and the skills (and experience and support)needed by women business owners and the support programmes available to them will be discussed.

\section{Women Business Owners Worldwide}

The universal reasons for pursuing entrepreneurship and small business ownership are independence, achievement, income generation, challenge, increased flexibility and having more time available for family and personal interests (Scarborough 2011:35; Deakins \& Freel, 2012:85). Although the relationship between unemployment and entrepreneurship has been much debated, severalstudies have concluded that unemployment is a major reason for the start-up of a new business (Remeikiene \& Startiene, 2009:910; Startiene \& Remeikiene, 2009:67; Ligthelm, 2012:11418; Fritsch, Kritikos \& Pijnenburg, 2015:282). From a woman's perspective, these reasons for pursuing business owners hip confirm the possible suitability of entrepreneurship and business ownership for enabling women to express themselves economically (Scarborough, 2011:34). However, women who own businesses face the challenge of satisfying the dual and time-consuming demands of their domestic responsibility and their responsibility to generate a household income. Although business ownership can alleviate pressure, it can also create pressure, as women business owners, in reality, experience more (rather than less) work-family conflict than expected amidst the autonomy and flexibility that entrepreneurship can offer (Deakins \& Freel, 2012:85). Even though it is riskier for both genders to pursue business ownership instead of employment, a woman business owner may have to deal with the additional consideration of balancing the time available between herbusiness and her family (the work-life balance conundrum). As a result, women tend to deliberately keep their businesses small due to the dual responsibilities with in and outside the household (Deakins \& Freel, 2012:87).

Authors agree that women-owned businesses tend to be concentrated in the retail and service industries, which have lower entrance requirements and which seem to better suit the work-life situation women business owners have to manage (Scarborough, 2011:34; Deakins \& Freel, 2012:84; SBP, 2013:1). However, Deakins and Freel (2012:19) and Koellinger, Minniti and Schade (2013:213) concur that fewer women than men start and own businesses, and that it is generally claimed that business opportunity and success are less available to and less experienced by women compared with men. Blundel and Lockett (2011:336), as well as Deakins and Freel (2012:83) provide some insight as to why the start-up rate of women-owned businesses is substantially lower than that of bus inesses owned by men, and why the volume of women-owned businesses is low compared with that of businesses owned by men. These authors explain that the actual number of women-owned businesses can be larger than what is evident from statistics, since when women act as co-owners with men or as "hidden entrepreneurs" (who contribute as members of a family business), such businesses are not officially defined as "women-owned". Women still tend to be marginalised, and since they are perceived as the weaker gender (both physically and emotionally), they are constrained in their efforts to find prospects in a male-dominated society. In Africa specifically, these constraints are rooted in societal attitudes towards women's role in the economy, traditional roles and responsibilities, patriarchal societal conventions, 
discrimination, male-dominated industries, prejudice and chauvinism (Kumar, Mohan, Vijaya \& Lokeshwari, 2013:101; Martin \& Barnard, 2013:32; SBP, 2013:9; World Wide Worx, 2014; Asare, Akuffobea, Quaye \& AttaAntwi, 2015:27).

Women do not only suffer the consequences of economic subordination, but they also lack confidence in their entrepreneurial skills, which has been highlighted as one of the main reasons for the low rate of women business ownership worldwide (Deakins \& Freel, 2012:85-86; Koellinger et al. 2013:214). Also, when business culture and business networks exclude women, a lack of confidence most probably results. Other reasons for the lower rate of women entrepreneurship and business ownership could be the tendency of women to be more self-screening (i.e. experiencing feelings of inadequacy, low self-efficacy and low self-confidence), and the tendency of women to place higher demands on themselves than men do (Deakins \& Freel, 2012:85; Martin \& Barnard, 2013:7). Martin and Barnard (2013:5, 21-23), in support of other research findings, state that working women tend to focus on doing a good job and on contributing to the functioning of the business within certain personal constraints. The se constraints are mainly the result of a lack of time to balance the bulk part of nurturing a family with building a career or being the owner/manager of a small business, as previously discussed.

Since most women prefer businesses in services or retailing, as already mentioned, the perception is that such businesses tend to be smaller in size in terms of employment and income. In The 2014 State of Women-owned Businesses Report (an annual publication on American women-owned businesses commis sioned by American Express OPEN based on published information from the US Census Bureau) (American Express OPEN, 2014) it is concluded that despite American women-owned busines ses growing at rates exceeding the national average, such businesses are still smaller in terms of employment and income than the average American business. The difficulty of being a woman business owner in America as a developed country is confirmed by general research findings that women-owned businesses are also less likely to grow than bus inesses owned by men (Deakins \& Freel, 2012:85). Deakins and Freel (2012:19) mention the perception that being small implies that less external funding is required and confirm that women-owned businesses are more likely than men-owned businesses to be undercapitalised at start-up. The issue of fair access to capital remains controversial, even in developed countries. Cantwell (2014) concludes in the Majority Report of the US Senate Committee on Small Business and Entrepreneurship that American women business owners still face challenges in obtaining fair access to capital. Undercapitalis ation can probably be attributed to the general perception that women as a group tend to have less financial wealth than men. Marlow's (2014) point of view is that the lower performance of women-owned businesses is not in fact due to a skills shortage or a lack of competence, but can be the direct result of women's socio-economic positioning and women not having equal access to capital. Marlow (2014) states that although women-owned busines ses are undercapitalised, they do not necessarily underperform. She argues that if "stereotypical masculinised models of business operations" are used to benchmark women-owned businesses in terms of aspects such as growth ambitions, formal funding and full-time involvement, such businesses are wrongly labelled as underperformers, as they could in fact be performing well if growth in employment, sales, turnover, profit margins and market share are used as performance indicators.

Despite the universal challenges faced by women business owners, Allen (2012:20) indicated that in 2012 women already comprised one-third of all entrepreneurial activity worldwide, which is in line with the trend mentioned in The 2014 State of Women-owned Businesses Report (American Express OPEN, 2014). Although recorded entrepreneurial activity rates for women remain lower than those for men, the differences between genders in entrepreneurship have narrowed in many countries (Blundel \& Lockett, 2011:336). Furthermore, Marlow (2014) and Deakins and Freel (2012:83) agree that researchers should keep in mind that co-owning women can have as much influence in a business as their male partners, as already mentioned. This could imply that gender differences in entrepreneurship and small business ownership may be less distinct than what research results show.

For this study it was assumed that the negative factors experienced by women small business owners worldwide as discussed have played a role in Soweto Township, but it is postulated that women business owners are in the process of overcoming these hindrances to start owning their rightful place in the South African business environment.

The next section will focus on the state of women business ownership in South Africa. 


\section{Women Business Ownership In South Africa}

Upon reflecting on the situation experienced by South African women-owned businesses, various recent literature sources paint a rosy picture of the state of local businesses. The literature sources consulted refer to various indices (such as the SME Growth Index), reports and surveys (such as the GEM and SME surveys), as well as academic research referenced in the discussion that follows. Before discussing the findings from these documents, some background needs to be provided on the SME Growth Index and the SME survey. The SME Growth Index is a multiyear research project by the SBP (Small Business Projects, formally registered as a section 21 not-for-profit company) geared towards establishing a solid evidence-based understanding of South A frica's SMEs. This annual survey tracks the experiences of a panel of 500 established small businesses in the manufacturing, business services and tourism sectors. The so-called SME Survey (conducted by a local research firm called World Wide Worx) annually investigates the impact of business factors on the competitiveness and success of SMEs. The findings from the SME Survey are based on 1400 telephonic interviews with a randomly selected sample of decision-makers at South African SMEs, consisting of companies across all vertical sectors with 2 to 200 staff members.

Although many negative findings pertaining to the performance of women bu siness owners have been reported, other findings are positive and encouraging, which creates the expectation of the emergence of a community of successful women business owners. The positive change in the activity and performance of women-owned businesses is reflected in the way that the facts related to these businesses are presented, as seenbelow. The following discussion will provide an overview of both the negative and positive developments in business ownership by women in South Africa by focusing mainly on the past five-year period, which will be used as a criterion of the success for SMMEs.

An examination of the history of South African businesses reveals that women-owned businesses showed slower growth than men-owned businesses in the pre-1994 period, which was similar to worldwide research findings (McPherson, 1996:270). At that stage (before 1994), a complicating factor in South Africa was that the struggle of black women constituted a battle against inequities in terms of both gender and race (Scott et al. 2012:549). The multi-country Global Economic Monitor (GEM) surveys, which included South Africa, have consistently confirmed that early-stage entrepreneurial activity shows gender sensitivity which can be attributed to cultural, societal and economic reasons. The 2014 GEM survey by Herrington, Kew and Kew (2014) confirmed previous GEM surveys in that while early-stage entrepreneurial activity in South Africa is mainly the preserve of men, there are no differences between the genders in terms of individual attributes, such as perceived opportunities and perceived capabilities. The 2013 SME Growth Index revealed that the differences between genders operating in the formal SME sectors were "overshadowed by their fundamental similarities" of being driven by commercial imperatives (SBP, 2013). From both the 2013 SME Growth Index (SBP, 2013) and Tagg and Wilson's (2012) research, it can be claimed that both men and women are equally capable of demonstrating characteristics such as initiative-taking, being active, and being independent, decisive and self-confident.

Based on the 2014 SME Survey (World Wide Worx 2014) it is reported that despite the low level of business ownership by women, a woman-owned small business is more likely to be profitable than a small business owned by a man. The 2013 SME Growth Index offers a positive overview of women business owners in South Africa's formal sectorin 2013 (SBP, 2013), which is largely in line with findings globally and in the GEM Reports. Focusing on the selected results given below of the 2013 SME Growth Index (SBP, 2013) pertaining to South African formal womenowned businesses compared with men-owned businesses, the following trends are observed regarding the way in which women business ownership is developing:

- The motivations for starting a business are a combination of opportunity and necessity factors among both men and women and include exploiting a market opportunity, seeking avenues of personal interest or fulfilment, leaving an unfavourable working environment and taking over a family business.

- The average turnover is lower for women-owned businesses.

- In line with global trends, women business owners have less business experience; they exhibit far more modest growth aspirations and their businesses are smaller in both turnover and the number of employees.

- Women-owned businesses have been operating for a shorter period of time (defined as operating for a period of nine years and less). 
- Women-owned businesses have higher average turnover (more than double) a mong the busines ses which are less than five years old.

- Women indicate far less that their motivation for the business lies in a quest for independence.

- Women are less educated, but a third have obtained a degree or postgraduate qualification.

- Although both genders have work experience prior to starting their businesses, fewer women owners obtained previous specific entrepreneurial experience by operating anotherbusiness.

- Women show less interest in expanding into new markets outside South Africa. They are more likely to have a geographically localised client base.

- No significant differences in growth aspirations are expressed by either of the genders. Women show slightly higher growth aspirations and also stress the importance of recognition of their business achievements.

- Women are less likely to take risks, although this difference is not extreme. Both genders are open to risk, but women label themselves as being cautious.

- Women business owners are more positive, optimistic and confident about the business environment and the future, and as a result believe that it has become easier to do business (for example to make commitments and investments to make growth possible).

From the 2013 SME Growth Index (SBP, 2013) it can be seen that although women operating in the formal SME environment do mention that cultural mores and family responsibilities hamper their activity in business, concems about chauvinism, prejudice and gender discrimination were not mentioned as impediments by the women business owners. In terms of jointly-owned SMEs (SMEs with both male and female owners) in South Africa, the 2014 SME Survey (World Wide Worx, 2014) shows that these busines ses are not as profitable as expected, which might indicate additional difficulties attributable to the differing personalagendas and management styles of spouses (or partners) in business.

In summary, both the 2013 SME Growth Index and the 2014 SME Survey conclude that the women business owners who acted as respondents in the period of investigation seem to be positively geared to growth in the current business environment.

The positive trends experienced in women-owned businesses worldwide is reflected in the position held by South Africa on the 2014 Gender Global Entrepreneurship and Development Index (2014 Gender-GEDI) (GEDI, 2014). This index was produced by the Global Entrepreneurship and Development Institute (GEDI) through an analysis of the conditions fostering high-potential female entrepreneurship in 30 countries for two consecutive years (2013 and 2014). Following a holistic approach, GEDI analysed the conditions that foster high-potential female entrepreneurship development by combining individual and institutional characteristics that can act as either drivers or inhibitors in the process. In 2014, South Africa occupied eleventh place, together with South Korea and China, on the Gender-GEDI (GEDI, 2014) - this placed South Africa among the so-called moderate performers, together with other emerging countries. This indicated the presence of a reasonably good business environment and fairly good access to resources, which create an enabling environment that supports the business cycle from start-up to exit. These countries also tend to perform well in terms of women's willingness to take risks, and in terms of the fact that they are not deterred by failure. The Index showed that when South Africa is grouped with other African countries, such as Ghana, Nigeria and Uganda, the African region is characterised by a high level of female entrepreneurial drive that is reflected in the development of successfulsmall businesses.

According to The Global Gender Gap Report 2014 (World Economic Forum, 2014), the World Economic Forum ranks South Africa 18th out of the 142 countries surveyed with regard to the degree of progress made in terms of reducing the gender inequality gap in the four key areas of economic participation, education, politics and health. According to the report, South Africa can serve as a role model country in terms of the equitable allocation of resources between genders.

In a survey conducted by Peters, Van Gensen, Is aacs, Botha and Naicker (2014:1129) among SMME owners/managers in the provinces of Western Cape and KwaZulu-Natal in South Africa, the successful performance by women owner/managers could be attributed mainly to respondents having equal access to resources (for example finance), as 
well as diminished constraints in terms of their competencies and a social tendency to pursue higher education. These findings are aligned with the conviction expressed by Ahl (2006), Ahl and Marlow (2012:556) and Henry, Foss and Ahl (2015:19), based on liberal feminist theory, that there should be no difference in the performance of businesses, irrespective of gender, provided women experience no discrimination in access to resources (finance and education).

Different opinions exist on whether the good performance of women-owned businesses could be the spill-over effect of legislation in South Africa stating that in the new political dispensation after 1994 (post-apartheid) a certain percentage of government positions should be held by women. On the one hand, the 2012 GEM Women's Report (Global Entrepreneurship Monitor 2012 Women's Report, 2012:14) as compiled by Kelley, Brush, Greene and Litvosky (2012) mentions the positive influence that legislation has had on the mind-set of business in general, with increasing numbers of women entering the labour market and holding top positions. On the otherhand, the 2014 SME Survey (World Wide Worx, 2014) states that despite the South African government's effort to provide women with job experience in parliament as their workplace as a way to reduce genderinequality, the approach has not permeated the rest of South Africa's economy.

\section{Physical Location as an Indicator of Small Business Success}

A general finding (i.e. one that does not distinguish between genders) in the 2014 SME Survey (World Wide Worx, 2014) relates to the importance of location to all South African SMEs. According to this survey, SMEs located in cities are more likely to be profitable than those located in smaller towns or rural areas. In the aforementioned survey it is concluded that the gap between the profitable SMEs in cities and those in towns could be an indication that despite opportunities being available in towns, the challenge lies in transforming such opportunities into profitable businesses. In terms of location, the survey highlighted that personal interaction with customers remains cardinal in the success of SMEs, even though technology enables business owners to establish enterprises almost anywhere. Due to location being established as vital for entrepreneurship development and very significant in the prediction of small business performance (Minai \& Lucky, 2011:181, 185), the location decision of small business owners needs to be analysed. In a study by Okpara and Wynn (2007:33), location was identified as one of small business owners' major obstacles in terms of business growth in that their businesses were inaccessible to customers. Despite location being identified as a reason for small business failure, international studies determined that business owners (especially in rural areas) might nevertheless locate their businesses in areas where they were born and rely on their social networks to stay in business amidst the economic challenges of such areas (Robinson, 2007:45, 54). The argument also holds true for family-owned businesses that have been operating for generations. Conway and Sheridan (2005:70) found that maintaining a business in a regional location would rely on customer relations (based on marketing skills) and strategic alliances. When studying the s patial distribution of shopping malls, Ertekin, Dokmeci, Unlukara and Ozuz (2008:144, 154) emphasise that consumers will not travel far to purchase daily items, and therefore, a convenience store could be sustainable despite a relatively small catchment area. In their research, these authors found that low-income peripheral neighbourhood malls with limited transport facilities and lower ratios of car ownership have smaller catchment areas than the bigger malls. Anselmsson (2006:133) concluded in his study on location as one of the determinants of shopping centre patronage that a customer would go to a distant shopping centre once or twice and be satisfied, but that the distance and effort would result in his or her visiting a similar, geographically more convenient, centre more frequently.

\section{Women Business Owners' Self-Awareness of Their Need for Support And Skill Development}

Education and training, as mentioned in the 2012 GEM Women's Report (Global Entrepreneurship Monitor 2012 Women's Report, 2012:4) are important both in empowering women entrepreneurs with skills, and in contributing positively to their confidence and self-perception, which are much-needed attributes for becoming a successful business owner. Although it is generally agreed that all busines s owners should be skilled in managing their businesses, small business owners are not always aware of the skills they need and the support that is available to them. For support programmes to be successful, two-way communication should be facilitated between business owners and the providers of support. 


\section{Skills, Experience and Exposure Needed by Small Business Owners}

In developing countries, human capital (defined as the task-related skills and knowledge that can be obtained through investments in education, on-the-job training and experience) can provide a small business with a competitive advantage. Acquiring human capital is essential in all development phases of business survival, growth and successful closure, especially in the case of so-called necessity entrepreneurs, who often exhibit low literacy levels (Bates, 2005:356; Unger, Rauch, Frese \& Rosenbusch, 2011:343, 345). Unger, Keith, Hilling, Gielnik and Frese (2009:23) emphasise that continuous learning and acquisition of new knowledge are es sential for successfultask accomplishment in small businesses. As already discussed, some of the major reasons for the low rates of women entrepreneurship (and business ownership by women in general) have been identified as women's lack of skills, lack of confidence in their entrepreneurial skills, fear of failure and lower exposure to fellow business owners (Deakins \& Freel, 2012:8586; Koellinger et al. 203:214, 229).

In the literature, various skills are discussed as being essential to small business success, and the lack thereof could result in business failure. A lack of management skills often leads to poor management decisions, which could hamper growth or lead to failure (Mbonyane \& Ladzani, 2011: 553; Okpara \& Wynn, 2007:31; 32). Ejembi and Ogiji (2007:7) refer particularly to small business owners' lack of skills in terms of record-keeping and risk management as reasons for failure. In the study conducted by Tushabomwe-Kazooba (2006:31-32) among Ugandan entrepreneurs, a lack of business management skills and a lack of knowledge regarding market needs were identified as some of the major reasons for small business failure. In the research conducted by Conway and Sheridan (2005:72) among business owners in the mid-size regional area of Armidale, Australia, the fact that women verbalised their need for advice on marketing and strategic planning may be an indication of their awareness of the importance of and need for these skills in terms of the sustainability of their businesses. In some busines ses lower priority appears to be assigned to marketing due to the owners' lower level of education, a subsequent lack of awareness of marketing skills and the false perception among these business owners that marketing is useful only to larger businesses (Blankson, Motwani \& Levenburg, 2006:572). This apparent ignorance is, however, negated by the aforementioned authors when they conclude that small business owners can have a "distinct marketing style" without formally applying marketing planning and research. The fact remains that entrepreneurs must constantly apply their marketing skills (either formally or informally) to obtain and use relevant marketing information related to customers and competitors in order to decide on their unique marketing mix for serving their customers competitively (Keh, Nguyen \& Ng, 2006:609).

Women also need increased exposure to fellow business owners and industry to observe different approaches to business problems. In this regard, Conway and Sheridan (20065:72) suggest that business owners in regional areas can use both bonding strategies to build social capital through close relationships with their community and local friends and family as well as bridging strategies to link to industry and professional networks.

\section{Small Business Owners Expressing Their Need for Support}

The ability of women business owners to recognise and articulate their need for business support, skills, engagement and recognition would facilitate the empowering process bi-directionally (i.e. two-way communication is needed with government and other support institutions on the one hand providing information about the support programmes available, and on the other hand receiving information about the specific support needs experienced by the women business owners). Mbonyane and Ladzani (2011:557) conclude from their research that communication between the South African government and small business owners is poor. In their research conducted in the regional areas of Australia, Conway and Sheridan (2005:64) suggest that possible reasons for only a few women indicating that they found support agencies crucial could be a lack of awareness of support programmes or even that the women found the services inadequate after accessing them.

From the above it can be concluded that the successfulformulation and implementation of support programmes and policies to support women business owners is likely to depend first on bridging the information gap between the specific needs of women business owners in terms of support, and second on the different support programmes available to them. 


\section{Support Programmes Available to Women}

Researchers have concluded that business ownership by women in South Africa should be promoted by providing support in the form of advice, training, access to finance and networks, gender-balanced mentoring in work matters and balancing emotional and work-life issues (Martin \& Barnard, 2013:24, 26; Peters et al. 2014:1136). The GEM 2012 Women's Report (Global Entrepreneurship Monitor 2012 Women's Report, 2012:4) suggests that support for women business owners (which could take the form of advice and services) should take place using support networks, women mentors and local women as role models. The South African government has shown commitment to the empowerment of women in several ways, such as focusing programmes on women, establishing funds and grants through the Industrial Development Corporation, appointing women in parliament and formulating the Department of Trade and Industry's framework on Gender and Women's Economic Empowerment. Another initiative launched by the Department of Small Business Development in South Africa in 2004 is the Small Enterprise Development Agency (Seda) (Department of Small Business Development, 2004), with a mandate to implement government's small business strategy; design and implement a standard and common national delivery network for small enterprise development; and integrate government-funded small enterprise support agencies across all tiers of government.

In South Africa, the low level of utilisation of support programmes by small businesses has resulted in them not benefiting as much as they might from available support. It was realised that success would be achieved not only through formulating policies and support programmes, but also through ensuring that women business owners are aware of the assistance offered to them and can access this support (Department of Small Business Development, 2004; Orser and Madill, 2006:ix). In response to this need, the Department of Trade and Industry decided to develop a National SMME Directory in 2010 (Department of Trade and Industry, 2010), in an attempt to provide a single source of information on all available support programmes to SMME business owners.

\section{RESEARCH OBJECTIVES}

Against the backdrop of the state of business ownership by women both internationally and loc ally, as well as the support already available to women-owned SMMEs, the question arose as to how female owners/managers of SMMEs perform in serving the needs of residents of Soweto Township. Answers to this research question were sought through the achievement of the secondary objectives of investigating the role played by gender in terms of certain biographical characteristics of small business owners (such as the age of the business owner, the business owner's level of education, business support needed and level of involvement in the business), as well as in terms of selected business characteristics (such as the reasons for starting the business, physical location and age of the business and income growth patterns). Seven hypotheses (see table 2) were formulated to determine the as sociation between gender and aspects related to the business owner, as well as between gender and aspects related to business operations.

\section{RESEARCH METHODOLOGY}

The subsequent discussion will focus on the research design and a description of the findings of the study.

\section{Research Design}

Due to the dynamic nature of SMMEs in South Africa and the particular place of women in SMMEs it was decided to focus on a specific research area where a vast number of SMMEs were operating. To this end, the research focus fell on Soweto Township as the study area. Soweto is a large township established in 1904 which is home to more than a million residents and contributes $3.7 \%$ to the Gross Domestic Product (GDP) of Johannesburg, which equa tes to about R30 billion a year, to the economy of the province of Gauteng. The estimated consumer spending power is in the region of R5 billion per annum (Steyn, 2013).

Soweto was further chosen due to the developments in the retail sector that have taken place over the past decade, with a resultant increase in the number of formal SMMEs, which could include a considerable number of women owners and managers of SMMEs. For this study, a descriptive research design was followed. A quantitative survey approach was used and data were analysed to gather information on the key characteristics and dynamics of SMMEs 
in Soweto. The survey followed a multidimensional approach in investigating various aspects of the functioning of small businesses.

The study area encompassed all the formal business areas/stands in Soweto. These included shopping malls, large shopping areas (outside shopping malls) and all the smaller shopping centres and single demarcated business stands in the township and industrial areas.

The universe of the study comprised all the formal SMMEs located in the Soweto Township area. The focus was purely on researching the formal businesses operating in the area. Formal businesses formpart of the official economy of the country and operate from permanent structures with relatively sophisticated infrastructural, financial and technological systems and are also incorporated into the formal economic and fiscal reporting structures of South Africa. The reason for focussing on formal SMMEs in this study is in line with the aim of the 2013 SME Growth Index, with its focus on understanding the driving forces behind the formal sector as a more transformative contributor to wealth creation, economic growth and innovation than informal survivalist businesses (SBP 2013:1).

The evaluation criteria used to qualify for inclusion in the Soweto SMME sample comprised the following:

- Be an independent business with any of the following ownership structures: sole proprietor, partnership, cooperative, CC (close corporation) or company (Pty Ltd or Ltd).

- Be located on a business stand and conduct business from a fixed brick and mortar structure.

\section{Sample Elements}

The sample elements of each of the selected SMMEs comprised either the owner or manager of the business and included both male and female owners and managers. This was done because the activities of the business could be verified only by the person responsible for the business decision making regarding the SMME.

\section{Sample Plan Design}

The sample plan design includes a description of the sampling methodology, the sample size and the research instrument.

Sampling Methodology

The lack of an up-to-date list of formal small businesses in Soweto rendered the determination of the exact population size for the study impossible. To determine a sample size of any consequence, a multi-stage quota sample design was followed.

Sample Size

The lack of a properly defined population resulted in the use of central limit theory, which postulates that using a sufficiently large number of respondents will result in an approximately normal distribution (Van Zyl, 2014). Taking the research budget into consideration, the sample size was set at 650 businesses in the Soweto Township area, which was deemed to be acceptable for the purpose of the study. The total sample was allocated according to the following seven SMME segments from which quota s ampling was drawn:

\section{Shopping Malls}

A total of up to 100 formal SMMEs were to be interviewed in any or all of the following developed large shopping malls (termed primary shopping centres): Bara Mall, Maponya Mall, Jabulani Mall, Dobsonville Mall, Naledi Mall and Protea Mall. All SMMEs who adhered to the inclusion criteria and who were willing to participate were interviewed. 


\section{Smaller Shopping Centres (Outside malls)}

Smaller shopping centres in the survey area were selected at random with an instruction that at least 50 SMMEs be interviewed in each of the following stratified segments:

- Shopping centres with 2 to 5 businesses in the shopping centre with no more than two businesse s per centre. Stand-alone shops were also included in this segment.

- Shopping centres with between 6 and 10 businesses. Any business was selected at random, and every second business after that in the specific centre.

- Tertiary shopping centres with between 11 and 20 businesses in the centre. Any business was selected at random, and every third business after that in the specific centre.

- Secondary shopping centres with more than 20 businesses in the centre. Any business was selected at random, and every third business after that in the specific centre.

Due to the small number of shopping centres with more than 10 businesses in Soweto, the quotas allocated to tertiary and secondary shopping centres were not attained.

$\underline{\text { Industrial Areas }}$

At least 50 manufacturers were to be interviewed in industrial areas. Due to the relatively small number of industrial SMMEs in the study area, all respondents who were willing to participate were interviewed.

\section{Research Instrument (Questionnaire)}

The questionnaire covered a multi-disciplinary range of functional areas and included the demographics of the res pondents, entrepreneurship activities, supply chain management and stock control, the competitive position of small businesses, internal store operations, business administration and the marketing activities performed by these SMMEs.

\section{RESEARCH FINDINGS}

A total of 495 respondents operating in the retail sector completed the survey, constituting $76.2 \%$ of the population of the study. The questionnaire, however, did not include any questions on the nature of the retail activities preformed by the respondents. Of the 495 respondents, 340 were men and 155 women. Due to the focus of the study, it was decided to report only on the women business owners/managers interviewed.

\section{Profile Description of the SMMEs Interviewed in Soweto}

The following aspects will be covered in the discussion of the key profile aspects of the women small business owners/managers interviewed:

- Distribution of the respondents by gender

- Age of the respondents

- Level of education of the business owner/manager

- Business support needed by the business owner/manager

- Occupancy of business

- Reasons for starting the business

- Physical location of the business

- Age of the businesses

- Growth of the business (Turnover/total income patterns during the preceding year)

Information regarding the above was condensed in Table 1. 
Table 1. Key profile aspects of the respondent base of SMMEs in Soweto and, more specifically, the women owners/managers

\begin{tabular}{|c|c|}
\hline Gender & Percentage \\
\hline Male & 68.7 \\
\hline Female & 31.3 \\
\hline Total & 100.0 \\
\hline \multicolumn{2}{|l|}{ Age of women owners/managers } \\
\hline $19-30$ years & 9.1 \\
\hline $31-40$ years & 23.3 \\
\hline $41-50$ years & 34.6 \\
\hline $51-60$ y ears & 23.3 \\
\hline$>61$ years & 9.7 \\
\hline Total & 100.0 \\
\hline \multicolumn{2}{|l|}{ Level of education of women owners/managers } \\
\hline No schooling & 1.3 \\
\hline Grade $1-6$ & 9.0 \\
\hline Grade $7-12$ & 64.5 \\
\hline Technical training $<3$ years & 13.1 \\
\hline University/College $\geq 3$ years & 11.1 \\
\hline Total & 100.0 \\
\hline \multicolumn{2}{|c|}{$\begin{array}{l}\text { Business support needed by women business owners/managers (three most } \\
\text { important interventions required) }\end{array}$} \\
\hline Marketing assistance & 37.7 \\
\hline Business skills training & 21.4 \\
\hline Business information & 15.6 \\
\hline \multicolumn{2}{|l|}{ Part-time/Full time in business } \\
\hline Part-time & 0 \\
\hline Full time & 100.0 \\
\hline Total & 100.0 \\
\hline \multicolumn{2}{|l|}{ Reason for starting the business } \\
\hline Unemployed & 45.8 \\
\hline Family business & 20.6 \\
\hline Business opportunity & 29.1 \\
\hline Supplement income & 3.9 \\
\hline Other & 0.6 \\
\hline Total & 100.0 \\
\hline \multicolumn{2}{|l|}{ Physical location of the business } \\
\hline Large shopping mall (primary shopping centre) & 5.9 \\
\hline Stand-alone shop & 13.0 \\
\hline Small shopping centre $2-5$ shops & 61.4 \\
\hline Shopping centre $6-10$ shops & 10.5 \\
\hline Shopping centre 11-20 shops (tertiary shopping centre) & 2.0 \\
\hline Shop ping centre $>20$ shops (secondary shopping centre) & 2.0 \\
\hline Industrial area & 5.2 \\
\hline Total & 100.0 \\
\hline \multicolumn{2}{|l|}{ Age of the business } \\
\hline$<1$ year & 10.3 \\
\hline$>1$ year $-<3$ years & 7.7 \\
\hline$>3$ years $-<5$ years & 19.4 \\
\hline$>5$ years & 62.6 \\
\hline Total & 100.0 \\
\hline \multicolumn{2}{|l|}{ Turnover/total income patterns during the preceding year } \\
\hline Expanded & 55.3 \\
\hline Contracted & 19.0 \\
\hline Same & 25.7 \\
\hline Total & 100.0 \\
\hline
\end{tabular}

Source: Compiled by authors from survey results. 
Regarding the key profile aspects of the female respondents, the following can be observed:

Roughly two-thirds of the respondents interviewed were men while roughly one-third were women. Due to the focus of the study it was decided to concentrate on the women business owners and managers as previously mentioned. The remainder of Table 1 provides information regarding the women business owners and managers interviewed in Soweto.

- Age: The majority of women business owners and managers were between 31 and 60 years of age, and constituted $81.2 \%$ of the respondent group. The smallest category was women business owners and managers between 19 and 30 years of age.

- Level of education: The majority of the respondents had some form of secondary schooling up to Grade12. Nearly $25 \%$ of the women respondents had a tertiary qualification.

- Business support needed: The most important form of business support needed by the women owners/managers was marketing assistance (37.7\%). This was followed by general business skills (21.4\%) and business information (15.6\%).

- Occupation: All of the women owners/managers were involved in a full-time capacity.

- Reason for starting the business: The main reason for starting a small business remains the scourge of unemployment, with $45.8 \%$ of the respondents citing this reason. A significant number of women business owners or managers indicated that they had started the business as a result of identifying a business opportunity (29.1\%), followed by $20.6 \%$ who indicated that they had joined a family business which had been an ongoing business concern.

- Physical location: There was a definite concentration of women business owners/managers in the smaller shopping centres (shopping centres with between 2 and 10 shops). Nearly $72 \%$ of the respondents were concentrated in these smaller shopping centres.

- Age of the business: The majority of the women respondents $(62.6 \%)$ had been involved in the business for more than five years, which is a substantial period and would indicate that they were successful in operating an SMME. These findings are in line with the general rule of thumb used by practitioners, as well as international statistics, that most small businesses fail within five years of start-up. Small Business Administration (2014), a United States government agency supporting small businesses, as well as official statistics in the United Kingdom (as quoted by Deakins \& Freel 2012:19) show that 50\% of small business cease trading by the fifth year.

- Growth in turnover/income: The women small business owners interviewed were doing well, in that $55 \%$ indicated that they had increased their turnover or total income in the past year.

From the descriptive information, it was clear that additional statistical testing was necessary. Inferential statistics was therefore used to determine the strength of the relationships between gender and certain characteristics (age categories; levels of education; type of business support needed; reas ons for starting the SMME; the physical location of the business; the duration of existence of the SMME; and the growth in turnover/income generated) with a specific focus to interpret the proportional female distribution in the cross -tabulations with the selected characteristics. To this end, a Chi-square analys is was done by using the Pearson Chi-Square test of independence to determine if there was a relationship between the female and male owners/managers and the selected characteristics. The Pearson Chi-Square is used as a non-parametric test of significance between the observed distribution of data among categories and the expected distribution based on the null hypothesis (Cooper \& Schindler 2011:469). Furthermore, Cramer's V was used to compare the strength of as sociation between the two variables in the classification tables. A Cramer V value of $\leq 0.10$ is considered a very weak association, whereas a value ranging from 0.11 to 0.18 is seen as weak. Values ranging from 0.19 to 0.29 are considered moderate and, therefore, a value of $>0.30$ indicates a strong association. A larger value for Cramer's V can thus be considered to indicate a strong relationship between the variables while a smaller value indicates a weaker relationship. 
Table 2. Hypotheses Testing

\begin{tabular}{|c|c|c|}
\hline Focus & Hypotheses & Findings \\
\hline $\begin{array}{l}\text { Gender and age } \\
\text { of business } \\
\text { owners/ } \\
\text { managers }\end{array}$ & $\begin{array}{l}\text { - H0 There is no association between female } \\
\text { and male ownership and their age. } \\
\text { - H1 There is an association between female } \\
\text { and male owners/managers and their age. }\end{array}$ & $\begin{array}{l}\text { - The Pearson Chi-Square test of independence } \\
\text { indicated that there is a statistically } \\
\text { significant association between female and } \\
\text { male owners/managers and their age at the } \\
5 \% \text { level of significance }(\mathrm{p}=0.012) \text {. } \\
\text { The value of Cramer's } \mathrm{V}, 0.162 \text {, indicated a } \\
\text { weak relationship. }\end{array}$ \\
\hline $\begin{array}{l}\text { Gender and level } \\
\text { of education }\end{array}$ & $\begin{array}{l}\text { - H0 There is no association between female } \\
\text { and male ownership and their level of } \\
\text { education. } \\
\text { - H1 There is an association between female } \\
\text { and male ownership and their level of } \\
\text { education. }\end{array}$ & $\begin{array}{l}\text { - The Pearson Chi-Square test of independence } \\
\text { indicated that there is a statistically } \\
\text { insignificant association between female and } \\
\text { male owners/managers and their level of } \\
\text { education at the } 5 \% \text { level of significance } \\
\text { ( } \mathrm{p}=0.177 \text { ). } \\
\text { The value of Cramer's V, } 0.125 \text {, indicated a } \\
\text { weak relationship. }\end{array}$ \\
\hline $\begin{array}{l}\text { Gender and type } \\
\text { of business } \\
\text { support needed }\end{array}$ & $\begin{array}{l}\text { - H0 There is no association between female } \\
\text { and male ownership and the type of business } \\
\text { support needed. } \\
\text { - H1 There is an association between female } \\
\text { and male ownership and the type of business } \\
\text { support needed. }\end{array}$ & $\begin{array}{l}\text { - The Pearson Chi-Square test of independence } \\
\text { indicated that there is a statistically } \\
\text { significant association between female and } \\
\text { male owners/managers and the type of } \\
\text { business support they need at the } 5 \% \text { level of } \\
\text { significance ( } \mathrm{p}=0.000) \text {. } \\
\text { The value of Cramer's V, } 0.375 \text {, indicated a } \\
\text { strong relationship. }\end{array}$ \\
\hline $\begin{array}{l}\text { Gender and } \\
\text { reason for starting } \\
\text { a business }\end{array}$ & $\begin{array}{l}\text { - H0 There is no association between female } \\
\text { and male ownership and the reason for starting } \\
\text { a business. } \\
\text { - H1 There is an association between female } \\
\text { and male ownership and the reasons for } \\
\text { starting a business. }\end{array}$ & $\begin{array}{l}\text { - The Pearson Chi-Square test of independence } \\
\text { indicated a statistically insignificant } \\
\text { association between female and male } \\
\text { owners/managers and the reasons for starting } \\
\text { a business at the } 5 \% \text { level of significance } \\
\text { ( } \mathrm{p}=0.293 \text { ). } \\
\text { The value of Cramer's V, } 0.036 \text {, indicated a } \\
\text { very weak relationship. }\end{array}$ \\
\hline $\begin{array}{l}\text { Gender and } \\
\text { physical location } \\
\text { of the business }\end{array}$ & $\begin{array}{l}\text { - H0 There is no association between female } \\
\text { and male ownership and the physical location } \\
\text { of the business. } \\
\text { - H1 There is an association between female } \\
\text { and male ownership and the physical location } \\
\text { of the business. }\end{array}$ & $\begin{array}{l}\text { - The Pearson Chi-Square test of independence } \\
\text { indicated that there is a statistically } \\
\text { significant association between female and } \\
\text { male owners/managers regarding the phy sical } \\
\text { location of their SMMEs at the } 5 \% \text { level of } \\
\text { significance ( } \mathrm{p}=0.042) \text {. } \\
\text { - The value of Cramer's V, } 0.163 \text {, indicated a } \\
\text { weak relationship. }\end{array}$ \\
\hline $\begin{array}{l}\text { Gender and } \\
\text { length of time in } \\
\text { business }\end{array}$ & $\begin{array}{l}\text { - H0 There is no association between the female } \\
\text { and male ownership and the duration being in } \\
\text { business. } \\
\text { - H1 There is an association between female } \\
\text { and male ownership and the duration being in } \\
\text { business. }\end{array}$ & $\begin{array}{l}\text { The Pearson Chi-Square test of independence } \\
\text { indicated a statistically significant association } \\
\text { between female and male owners/managers } \\
\text { regarding the length of time in business at the } \\
5 \% \text { level of significance }(\mathrm{p}=0.00) \text {. } \\
\text { The value of Cramer's } \mathrm{V}, 0.197 \text {, indicated a } \\
\text { moderately strong relationship. }\end{array}$ \\
\hline $\begin{array}{l}\text { Gender and } \\
\text { growth in } \\
\text { turnover/ } \\
\text { income generated } \\
\text { in the preceding } \\
\text { year }\end{array}$ & $\begin{array}{l}\text { - H0 There is no association between female } \\
\text { and male ownership and the turnover/income } \\
\text { generated by the business. } \\
\text { - H1 There is an association between female } \\
\text { and male ownership and the turnover/income } \\
\text { generated by the business. }\end{array}$ & $\begin{array}{l}\text { - The Pearson Chi-Square test of independence } \\
\text { indicated that there is a statistically } \\
\text { significant association between female and } \\
\text { male owner/managers and the turnover/ } \\
\text { income generated in the preceding year at the } \\
\text { 5\% level of significance }(\mathrm{p}=0.009) \text {. } \\
\text { The value of Cramer's V, } 0.139 \text {, indicated a } \\
\text { weak relationship. }\end{array}$ \\
\hline
\end{tabular}


From the hypotheses testing reported in Table 2 the following can be concluded:

1. Regarding the age of the women business owners/managers it is clear that fewer younger owners/ managers were interviewed than their male counterparts (in the age categories 19 to 40 years the ratio was $32.2 \%$ females versus $47.1 \%$ males). On the opposite side, it is also clear that more female owners/managers were interviewed that are older than their male counterparts (in the age categories 51 to $61>$ years the ratio was $32.8 \%$ females versus $22.6 \%$ males). This could indicate that fewer young females are following the route towards starting SMMEs than their male counterparts. On the opposite end, there is also a growing older component of female owners/managers than their male counterparts.

2. Regarding the level of education more female owners/managers have a grade 7 to 12 qualification than their male counterparts $(65.5 \%$ versus $53.5 \%)$. There are no further major differences between male and female owners/managers regarding their level of education.

3. Regarding the need for business support, there is a statistically significant difference between female and male owners/managers. Both genders state the primary universal need for marketing assistance for SMMEs, with women having a more dire need $(37.7 \%$ females versus $31.6 \%$ males). Male owners/managers, however, have a higher need for general business skills support than their female counterparts $(30.4 \%$ versus $21.4 \%)$.

4. Regarding the reason for starting a business, there is no statistically significant difference between female and male owners/managers.

5. Regarding the physical location of the business there is no statistically significant difference between male and female owners/managers regarding their location in the large shopping malls. There is, however, a major difference in that more female owners/managers are located in shopping centres with 2 to 5 shops (that is small shopping centres). Female owners/managers constitute $60.6 \%$ of the representation in this category while males constitute only $51.1 \%$. This confirms the literature that states that females who find retail businesses more appropriate might establish in smaller neighborhood malls to provide daily items to consumers (Ertekin et al. 2008).

6. Regarding the length of time in business, there is a clear statistically significant difference between males and female SMMEs regarding the time that the business has been in operation. More female owners/managers are in business for an extended period (defined as longer as five years) than their male counterparts (males $>5$ years $=44.2 \%$ versus females $=62.3 \%$ ), which is confirmed in the evidence regarding the age of female owners/managers.

7. Regarding the turnover generated in the preceding year, more women owners/managers have grown turnover $(55.2 \%)$ versus $49.4 \%$ male owners/managers. However, female owners/managers also reported more turnovers that contracted (18.3\% versus $11.9 \%)$. This serves as an indication that female owners/managers can be successful in the operations of their SMMEs.

\section{CONCLUSIONS AND RECOMMENDATIONS}

Although some statisticalsignificant differences were found between the male and female respondent groups, the gap between genders in terms of business ownership seems to have narrowed, as is the case worldwide as confirmed by Marlow (2014). As can be seen from their success in terms of the categories of age, the length of time in business and increased turnover, women business owners in Soweto seem to have developed into a force to be reckoned with in the township business environment. As a result, the recommendations from this study are aligned with the initiatives proposed for providing the impetus and momentum needed to grow successfulwomen SMME owners/managers.

It is recommended that South African small business decision makers bear the following in mind when developing programmes to empower small business owners:

1. Based on the gap, although busy narrowing, between gender groups in terms of business ownership, gender-specific programmes to promote business ownership should be developed to empower both genders in exploiting opportunities for wealth creation as mentioned in the findings of the 2013 SME Growth Index (SBP, 2013).

2. The fact that the research indicates that fewer young women enter into business ownership and that more older women own and grow small businesses should be further investigated to determine whether this is 
a general trend. If this were found to be the case, then several interventions would be needed. First, educational and training programmes offered to women business owners should not focus purely on start-ups, but should place a greater emphasis on growth, which is in line with the Global Entrepreneurship Monitor 2012 Women's Report (2012:4). Furthermore, it is stated in the 2014 GenderGEDI (GEDI, 2014) that an enabling environment should be established to provide support during all the various phases of start-up and growth until the business owner decides on an exit strategy. In this way, all age groups can be included and supported during all life cycle stages of the bus iness. Second, younger women may hesitate to enter into business ownership due to a lack of skills and mentorship. It could also be argued that in modern society, younger women are offered more opportunities to enter the South African workplace and stay there. Although a country's ability to foster and support the female entrepreneurial process depends on overall attitudes, norms, values, a legal environment that supports women's access to education, the appointment of women to leadership positions and the opportunity to gain work experience in different industries as proposed in the 2014 Gender-GEDI (GEDI, 2014), it is recommended in the 2014 SME Survey (World Wide Worx, 2014) that more South African women should be granted opportunities in the workplace to equip them for business ownership later on. As stated in the 2014 SME Survey (World Wide Worx, 2014), women should not only be appointed in government to implement gender equality, but should also increasingly be appointed in the private sector to obtain skills and gain much-needed confidence in preparation for business ownership.

3. As discussed in the literature, the successful formulation and implementation of support programmes would depend on effective two-way communication between programme developers and the business owners for whom these programmes are intended.

4. Further research is needed to determine the specific reasons why women SMME owners/managers prefer smaller locations. As previously explained, various reasons have been put forward for this, but further research is needed to ascertain the specific facts as they relate to South African women business owners/managers.

In conclusion, it can be stated that women owners/managers of SMMEs have shown remarkable growth and maturity in the dynamic and competitive environment in which they operate. However, much more needs to be done to further improve their position so that they can have their place in the sun.

\section{AUTHOR BIOGRAPHIES}

Orpha Cilliers is senior lecturer in the Department of Business Management at the University of South Africa (Unisa). She holds a PhD degree in Business Management and has been lecturing for 22 years. Her research interests include business management, marketing and small business management.

Johan Strydom is a professor in the Department of Business Management at the University of South Africa (Unisa). He holds a D Com degree in Business Management and has been lecturing at Unisa for 38 years. His research interests include small business management, marketing and international business.

\section{REFERENCES}

Ahl, H.J. (2006). Why research on women entrepreneurs needs new directions. Entrepreneurship Theory and Practice, 30(5):595-621.

Ahl, H.J. \& Marlow, S. (2012). Exploring the dynamics of gender, feminism and entrepreneurship: Advancing the debate to escape a dead end? Organization, 19(5):543-562.

Allen, K.R. (2012). New venture creation. 6th edition. USA: South-Western Cengage Learning.

American Express OPEN. (2014). The 2014 State of Women-Owned Businesses. [Online] Available from: http://www.womenable.com/content/userfiles/2014_State_of_Women-owned_Businesses_public.pdf. [Accessed: 201510-26]. customer segments. The International Review of Retail, Distribution and Consumer Research, 16(1):115-138.

Anselmsson, J. (2006). Sources of customer satisfaction with shopping malls: A comparative study of different customer segments. The International Review of Retail, Distribution and Consumer Research, 16(1):115138.

Asare, R., Akuffobea, M., Quaye, W. \& Atta-Antwi, K. (2015). Characteristics of micro, small and medium enterprises in Ghana: Gender and implications for economic growth. African Journal of Science, Technology, Innovation and 
Development, 7(1):26-35.

Bates, T. (2005). Analy sis of young, small firms that have closed: Delineating successful from unsuccessful closures. Journal of Business Venturing, 20:343-358.

Blankson, C., Motwani, J.G. \& Levenburg, N.M. (2006). Understanding the patterns of market orientation among small businesses. Marketing Intelligence \& Planning, 24(6):572-590.

Blundel, R. \& Lockett, N. (2011). Exploring entrepreneurship practices and perspectives. New York: Oxford.

Cantwell, M. (2014). $21^{\text {st }}$ Century barriers to women's entrepreneurship. Majority Report of the US Senate Committee on Small Business and Entrepreneurship, July (1). [Online] Available from: http://www.microbiz.org/wpcontent/uploads/2014/07/21st-Century-Barriers-to-Womens-Entrepreneurship.pdf. [Downloaded: 2015-10-27].

Conway, L. \& Sheridan, A. (2005). Women, small business and regional location. Rural Society, 15(1):55-76.

Cooper, D.R. \& Schindler, P.S. 2011. Business research methods. $11^{\text {th }}$ edition. Singapore: McGraw-Hill.

Deakins, D. \& Freel, M. (2012). Entrepreneurship and small firms. 6th edition. Berkshire: McGraw-Hill Higher Education.

Department of Small Business Development. (2004). Small Enterprise Development Agency. Information Booklet. [Online] Available from: http://www.seda.org.za/MyBusiness/Documents/Seda\%20Women\%20Owned\%20Enteprise\% 20Developement\%20Information\%20Booklet.pdf. [Accessed: 2015-10-29].

Department of Trade and Industry. (2010). National Directory of Small Business Support Programmes. [Online] Available from: http://bee.b1sa.co.za/National\%20Directory\%20of\%20Small\%20Business\%20Support\%20 Programmes\%202010\%20-\%20Master.pdf. [Downloaded: 2015-10-29].

Ejembi, S.A. \& Ogiji, P. (2007). A comparative analy sis of risks and returns of running small/medium and micro enterprises in North and Central Nigeria. Journal of Social Science, 15(1):7-15.

Ertekin, O., Dokmeci, V., Unlukara, T.\& Ozuz, E. (2008). Spatial distribution of shopping malls and analy sis of their trade areas in Istanbul. European Planning Studies, 16(1):143-156.

Fritsch, M., Kritikos, A. \& Pijnenburg, K. (2015). Business cycles, unemployment and entrepreneurial entry -evidence from Germany. International Entrepreneurship and Management Journal, 11(2):267-286.

GEDI (Global Entrepreneurship and Development Institute) (2014). The Gender Global Entrepreneurship and Development Index. [Online] Available from: http://i.dell.com/sites/doccontent/corporate/secure/ en/Documents/ Gender_GEDI_Executive_Report-2014.pdf. [Downloaded: 2015-08-26].

Herrington, M,. Kew, J. \&Kew, P. (2014). Global Entrepreneurship Monitor (GEM). . [Online] Available from: http://www.babson.edu/Academics/ centers/blank-center/global-research/gem/ Documents/GEM\%202014\%20Global\%20Report.pdf. [Downloaded: 2015-10-27].

Greenbank, P. (2001). Objective setting in the micro-business. International Journal of Entrepreneurial Behaviour \& Research, 7(3):108-127.

Henry, C., Foss, L. \& Ahl, J.H. (2015). Gender and entrepreneurship research: A review of methodological approaches. International Small Business Journal, January:1-25.

Herrington, M,. Kew, J. \&Kew, P. (2014). Global Entrepreneurship Monitor (GEM). . [Online] Available from: http://www.babson.edu/Academics/ centers/blank-center/global-research/gem/ Documents/GEM\%202014\%20Global\%20Report.pdf. [Downloaded: 2015-10-27].

Keh, H.T., Nguyen, T.T.M. \& Ng, H.W. (2006). The effects of entrepreneurial orientation and marketing information on the performance of SMEs. Journal of Business Venturing, 22:592-611.

Kelley, D.J., Brush, C.G., Greene, P.G. \& Litovsky, Y. (2012). Global Entrepreneurship Monitor (GEM) 2012 Women's Report. [Online] Available from: http://www.babson.edu/Academics/centers/blank-center/globalresearch/gem/Documents/ GEM\%202012\%20 Womens \%20Report.pdf. [Downloaded: 2015-10-27].

Koellinger, P., Minniti, M.\& Schade, C. (2013). Gender differences in entrepreneurial propensity. Oxford Bulletin of Economics and Statistics, 75(2):213-234.

Kumar, S.M., Mohan, H.S.C., Vijaya, C. and Lokeshwari, N. (2013). The role of women entrepreneurship in modern world. International Journal of Current Engineering and Technology, September:100-104.

Ligthelm, A.A. (2012). The viability of informal micro-businesses in South Africa: A longitudinal analysis (2007-2011). African Journal of Business Management, 6(46):11416-11425.

Marlow, S. (2014). Challenging the 'myth' of the underperforming female entrepreneur. International Institute for Small Business and Entrepreneurship. [Online] Available from: http://www.isbe.org.uk/Challengingthe\% E2\%80\%98myth\%E2\%80\%99oftheunder-performingfemaleentrepreneur. [Downloaded: 2015-07-18].

Martin, P. \& Barnard, A. (2013). The experience of women in male-dominated occupations: A constructivist grounded theory inquiry. SA Journal of Industrial Psychology/SA Tydskrifvir Bedryfsielkunde, 39(2):1-32.

Mbonyane, B. \& Ladzani, W. (2011). Factors that hinder the growth of small businesses in South African townships. European Business Review, 23(6):550-560.

McPherson, M.A. (1996). Growth of micro and small enterprises in southern Africa. Journal of Development Economics, 48:253-277. [Online] Available from: http://davinci. cascss.unt.edu/users/mcpherson/Papers/JDE\%20McPherson\%201996.pdf. [Accessed: 2015-10-27].

Minai, M.S. \& Lucky, E.O. (2011). The moderating effect of location on small firm performance: Empirical evidence. International Journal of Business and Management, 6(10):178-192. 
Minniti, M.\& Naudé, W. (2010). What do we know about the patterns and determinants of female entrepreneurship across countries? European Journal of Development Research, 22(3):277-293.

National Small Business Amendment Act of the Republic of South Africa. 2004. Pretoria Government Printer. (no. 29) [Online] Available from: https://www.thedti.gov.za/business_regulation/acts/small_business_amendment_act.pdf [Accessed: 2014-04-17].

Nieuwenhuizen, C. (2012). Entrepreneurship and small, medium and micro enterprises (SMMEs) in perspective. In Stry dom. J.W. (ed.) Entrepreneurship and how to establish your own business. Cape Town: Juta.

Okpara, J.O. \& Wynn, P. (2007). Determinants of small business growth constraints in a Sub-Saharan African economy. S.A.M. Advanced Management Journal, 72(2):24-35.

Orser, B. \& Madill, J. (2006). Sustaining the momentum: An economic forum on women entrepreneurs. Journal of Small Business and Entrepreneurship, 19(2):83-94.

Peters, R.M., van Gensen, G,. Isaacs, E.B.H., Botha, M.J.\& Naicker, V. (2014). Education and small business growth: A gender perspective of two divergent provinces in South Africa. International Business \& Economics Research Journal, 13(5):1127-1140.

Remeikiene, R. \& Startiene, G. (2009). Does the interaction between entrepreneurship and unemployment exist? Economics \& Management, 14:903-911.

Robinson, S. (2007). Business failure rates: A look at sex and location. Academy of Entrepreneurship Journal, 13(1):45-56.

SBP. (2013). Understanding women entrepreneurs in South Africa. SBP Alert, 3:1-10. [Online] Available from: http://www.sbp.org.za/uploads/media/SBP_Alert_Understanding_Women_Entrepreneurs_in_SA.pdf. [Accessed: 2015-10-19].

Scarborough, N.M. (2011). Essentials of entrepreneurship and small business management. 6th edition. England: Pearson.

Scott, L., Dolan, C., Johnstone-Louis, M., Sugden, K. and Wu, M. (2012). Enterprise and inequality: A study of Avon in South Africa. Entrepreneurship Theory and Practice, 36:543-568.

Simpson, M., Tuck, N. \& Bellamy, S. (2004). Small business success factors: The role of education and training. Education + Training, 46(8/9):481-491.

Small Business Administration. (2014). Office of Advocacy - Frequently asked questions. Retrieved from https://www.sba.gov/sites/default/files/advocacy/FAQ_March_2014_0.pdf. [Accessed:2015-01-16]

Startiene, G. \& Remeikiene, R. (2009). The influence of demographical factors on the interaction between entrepreneurship and unemployment. Inzinerine Ekonomika - Engineering Economics, (4):60-70.

Steyn, L. (2013). If it's survival of the fittest, Soweto will give you a run for your money. Mail \& Guardian, 18 October. [Online] Available from: http://mg.co.za/article/2013-10-18-00-if-its-survival-of-the-fittest-soweto-will-give-you-arun-for-y our-money. [Accessed: 2015-09-22].

Tagg, S. \& Wilson, F. (2012). Construing business owners: Are men and women really different? International Journal of Gender and Entrepreneurship, 2(1).

Tushabomwe-Kazooba, C. (2006). Causes of small business failure in Uganda: A case from Bushenyi and Mbararatowns. African Studies Quarterly, 8(4):27-35.

Unger, J.M., Keith, N., Hilling, C., Gielnik, M.M.\&Frese, M. (2009). Deliberate practice among South African small business owners: Relationships with education, cognitive ability, knowledge, and success. Journal of Occupational and Organizational Psychology, 82:21-44.

Unger, J.M., Rauch, A., Frese, M.\& Rosenbusch, N. (2011). Human capital and entrepreneurial success: A meta-analytical review. Journal of Business Venturing, 26:341-358.

Van Zyl, L.E. (2014). Research methodology for the economic and management sciences. London: Pearson, pp.178-180.

World Economic Forum. (2014). The Global Gender Gap Report 2014. [Online] Available from: http://www3.eforum.org/docs/GGGR14/GGGR_CompleteReport_2014.pdf. [Downloaded: 2015-10-281.

World Wide Worx. (2014). SME Survey 2014: Cloud grows, government does better, location is key and a gender surprise. [Online] Available from: http://www.smesurvey.co.za/reports/SME\%20 Survey \%20 summary \% 202014\%204.pdf. [Accessed: 2015-10-26]. 